\title{
Analisis Penyebaran Penyakit Covid-19 dengan Pengaruh Pengobatan Isolasi Mandiri dan Pengobatan Perawatan Rumah Sakit (Studi Kasus Penyebaran di DKI Jakarta)
}

\author{
Adam Victorio Alexis ${ }^{1, a)}$,Fariani Hermin Indiyah ${ }^{1, b)}$, Eti Dwi Wiraningsih ${ }^{1, c)}$ \\ ${ }^{1}$ Program Studi Matematika, Fakultas Matematika dan Ilmu Pengetahuan Alam, Universitas Negeri Jakarta \\ Email: ${ }^{\text {a) }}$ adam12victorio@gmail.com, ${ }^{\text {b) }}$ farianihermin@unj.ac.id, ${ }^{\text {c) }}$ Eti_Dwi@unj.ac.id
}

\begin{abstract}
In this research, a model for the spread of Covid-19 will be built using a differential equation because in the population there are two subpopulations who can spread the disease, there is one subpopulation who go through incubation period, and there are also 2 subpopulations who go through the treatment so the model will consists of compartments such as susceptible, exposed, asymptomatically infectious, symptomatically infectious, treatment 1 (self-isolation), treatment 2 (hospital care), and recovered. Analysis begins by calculating the disease-free equilibrium and endemic equilibrium. Before stability analysis, the model must be checked for adequacy in describing the disease spread. Stability analysis begins by forming the next generation matrix of the model with helps of jacobian matrix and chracteristic equation, then we can get basic reproduction number $\left(\Re_{0}\right)$. By entering the value of parameters according to data to the basic reproduction number, we get $\Re_{0}=0,851115$. The size of $\Re_{0}<1$ means that the disease will disappear from the population.
\end{abstract}

Keywords: differential equation, stability analysis, basic reproduction number

\begin{abstract}
Abstrak
Pada penelitian ini akan dibangun sebuah model penyebaran Covid-19 menggunakan persamaan differensial karena di dalam populasi terdapat dua subpopulasi yang dapat menyebarkan penyakit, satu subpopulasi yang menjalani masa inkubasi, dan dua subpopulasi yang menjalani pengobatan maka model akan terdiri dari kompartemen susceptible, exposed, asymptomatically infectous, symptomatically infectious, treatment 1 (isolasi mandiri), treatment 2 (perawatan rumah sakit), dan recovered. Analisis dimulai dengan mencari titik ekuilibrium bebas penyakit dan titik ekuilibrium endemik. Sebelum analisis kestabilan, model harus dicek kecukupannya dalam menggambarkan model penyebaran penyakit. Analisis kestabilan dimulai dengan membentuk matriks generasi selanjutnya dengan bantuan matriks jacobian dan persamaan karakteristik, kemudian bisa didapat bilangan reproduksi dasar $\left(\Re_{0}\right)$. Dengan memasukkan parameter-parameter yang sesuai dengan data ke dalam bilangan reproduksi dasar, didapatkan $\Re_{0}=0,851115$. Bilangan $\Re_{0}<1$ dapat diartikan penyakit akan menghilang dari populasi.
\end{abstract}

Kata-kata kunci: persamaan differensial, analisis kestabilan, bilangan reproduksi dasar 


\section{PENDAHULUAN}

Wabah Covid-19 ini mengubah banyak bidang di kehidupan manusia. Masalah kesehatan yang muncul adalah gejala umum berupa gangguan pernapasan akut seperti sesak napas, demam, dan batuk. Gejala berat yang muncul adalah sindrom pernapasan akut, pneumonia, gagal ginjal, dan terparah adalah kematian. Gejala berat ini muncul umumnya pada pasien usia rentan seperti usia lanjut, dan pasien dengan penyakit bawaan. Fasilitas kesehatan dan tenaga kesehatan pun menjadi perhatian mengingat jumlahnya terbatas menghadapi pasien yang bertambah. Wabah ini juga berdampak besar pada bidang ekonomi. Daya beli masyarakat turun karena banyak orang yang mata pencahariannya hilang akibat pembatasan sosial yang diperlukan. Dengan tidak tertahannya penyebaran virus ini maka pentinglah mengadakan penelitian dan membuat kebijakan yang mengurangi dampak wabah ini, termasuk penelitian bidang matematika yang bisa berkontribusi di dalamnya.

(Krisha dan Prakash, 2020) mengajukan model matematika penyebaran penyakit dari Covid-19. Pada model yang diajukan, diasumsikan virus penyebab penyakit Covid-19 muncul di reservoir (pasar baazar seafood). Warga dan pengunjung pasar baazar seafood yang terinfeksi dilambangkan dengan subpopulasi $\mathrm{W}$ dan dapat menginfeksi keseluruhan populasi. Secara keseluruhan, populasi diasumsikan dibagi menjadi subpopulasi susceptible (rentan), exposed (terpapar), asymptomatically infectious (dapat menularkan dengan tidak menunjukkan gejala), symptomatically infectious (dapat menularkan dengan menunjukkan gejala), dan removed (sembuh dan meninggal).

(Otunuga dan Ogunsolu, 2019) mengajukan analisis matematika dari transmisi penyakit tertentu menggunakan sebuah model proses stokastik susceptible-exposed-infectious-treatedrecovered dengan banyak fase pada infection dan treatments. Populasi awal diasumsikan secara keseluruhan rentan terhadap penyakit. Kemudian diperiksa hasil dari proses treatments dan fluktuasi eksternal pada tingkat transmisi, treatment (pengobatan), dan recovery (penyembuhan). Diasumsikan fluktuasi eksternal terjadi karena keragaman jumlah kontak antara individu terinfeksi dengan individu rentan yang bisa disebabkan oleh cuaca, semester sekolah, dan lain-lain.

Peneliti mengamati adanya subpopulasi yang dapat menularkan penyakit dengan menunjukkan gejala dan tanpa gejala, dan adanya subpopulasi yang menjalani pengobatan dengan isolasi mandiri dan perawatan rumah sakit pada proses penyembuhan dari Covid-19 di DKI Jakarta, Indonesia. Berdasarkan amatan terhadap data penyebaran penyakit Covid-19 dan penelitian-penelitian terdahulu, penulis tertarik menganalisis model matematika penyebaran penyakit Covid-19 dengan populasi keseluruhan dibagi menjadi subpopulasi (kompartemen) susceptible, exposed, asymptomatically infectious, symptomatically infectious, isolasi mandiri, perawatan rumah sakit, dan recovered. Kompartemen-kompartemen ini bisa disingkat menjadi SEAITR. Judul skripsi yang diajukan penulis adalah "Analisis Model Penyebaran Penyakit Covid-19 dengan Pengaruh Pengobatan Isolasi Mandiri dan Pengobatan Perawatan Rumah Sakit (Studi Kasus Penyebaran di DKI Jakarta)".

\section{LANDASAN TEORI}

Berdasarkan (Driessche dan Watnough, 2002), setelah membentuk model penyebaran penyakit, untuk menghitung bilangan reproduksi dasar dalam rangka meneliti kestabilan sistem, diperlukan matriks generasi selanjutnya. Dalam membentuk matriks generasi selanjutnya dan menghitung bilangan reproduksi dasar $\left(\Re_{0}\right)$, bedakan infeksi baru yang terjadi dalam populasi dari semua perubahan lain dalam populasi tersebut. Dimisalkan $x=\left(x_{1}, \ldots, x_{n}\right)$ dengan masing-masing $x_{i} \geq 0$, adalah jumlah individu pada masing-masing kompartemen. Kemudian kompartemenkompartemen tersebut disusun sehingga $m$ kompartemen pertama sesuai dengan individu yang terinfeksi.

Didefinisikan $X_{S}$ menjadi himpunan semua keadaan yang bebas penyakit.

$$
X_{s}=\left\{x \geq 0 \mid x_{i}=0, i=1, \ldots, m\right\}
$$


Misal $\mathcal{F}_{i}(x) \$$ adalah tingkat adanya infeksi baru pada kompartemen $i$, misal $\nu_{i}^{+}(x)$ menjadi tingkat perpindahan individu menuju kompartemen $i$, dan misal $\nu_{i}^{-}(x)$ menjadi tingkat perpindahan individu yang keluar dari kompartemen $i$. Model transmisi penyakit sebagai berikut:

$$
\dot{x}_{i}=f_{i}(x)=\mathcal{F}_{i}(x)-\mathcal{V}_{i}(x), \quad i=1, \ldots, n
$$

di mana $\nu_{i}=\nu_{i}^{-}(x)-\nu_{i}^{+}(x)$. Dikarenakan masing-masing fungsi mewakili sebuah perpindahan individu, maka fungsi-fungsi tersebut non-negatif. Model yang dibentuk harus memenuhi asumsiasumsi berikut:

(A1) Jika $x \geq 0$, maka $\mathcal{F}_{i}, v_{i}^{+}, v_{i}^{-} \geq 0$ untuk $i=1, \ldots, n$.

(A2) Jika $x_{i}=0$ maka $V_{i}^{-}=0$. Secara khusus, jika $x \in X_{s}$, maka $\nu_{i}^{-}=0$ untuk $i=1, \ldots, m$.

(A3) $\mathcal{F}_{i}=0$ jika $i>m$.

(A4) Jika $x \in X_{s}$, maka $\mathcal{F}_{i}(x)=0$ dan $\nu_{i}^{+}(x)=0$ untuk $i=1, \ldots, m$.

(A5) Jika $\mathcal{F}$ bernilai 0 , maka seluruh nilai eigen dari $D f\left(x^{*}\right)$ mempunyai bagian riil negatif. $D f\left(x^{*}\right)$ adalah turunan dari $\frac{\partial f_{i}}{\partial x_{j}}$ yang dihitung pada titik keseimbangan bebas penyakit $x^{*}$ (yaitu matriks Jacobian).

Dengan memperhatikan kondisi-kondisi di atas, $D f\left(x^{*}\right)$ dapat dipartisi seperti yang ditunjukkan lemma berikut.

Lemma. Jika $x^{*}$ adalah sebuah titik keseimbangan bebas penyakit dari model transmisi penyakit $\dot{x}$ dan $f_{i}(x)$ memenuhi (A1)-(A5), maka turunan-turunan $D \mathcal{F}\left(x^{*}\right)$ dan $D \mathcal{V}\left(x^{*}\right)$ dipartisi sebagai berikut

$$
D \mathcal{F}\left(x^{*}\right)=\left(\begin{array}{cc}
F & 0 \\
0 & 0
\end{array}\right), \quad D \mathcal{V}\left(x^{*}\right)=\left(\begin{array}{cc}
V & 0 \\
J_{3} & J_{4}
\end{array}\right),
$$

di mana $F$ dan $V$ adalah matriks $m \times m$ yang didefinisikan oleh

$$
F=\left[\frac{\partial \mathcal{F}_{i}}{\partial x_{j}}\left(x^{*}\right)\right] \text { dan } V=\left[\frac{\partial v_{i}}{\partial x_{j}}\left(x^{*}\right)\right] \text { dengan } 1 \leq i, j \leq m .
$$

Berikutnya, $F$ adalah non-negatif, $V$ adalah sebuah matriks-M non-singular, dan seluruh nilai eigen dari $I_{4}$ mempunyai bagian positif riil.

(Driessche, P., dan Watmough, J., 1990)

Produk $F V^{-1}$ disebut sebagai matriks generasi selanjutnya.

Bilangan reproduksi dasar $\left(\Re_{0}\right)$ didapatkan dari spectral radius matriks generasi selanjutnya, yaitu

$$
\Re_{0}=\kappa\left(F V^{-1}\right)
$$

di mana $\kappa(L)$ menunjukkan spectral radius dari matriks $L$. Spectral radius adalah nilai eigen terbesar dari matriks generasi selanjutnya.

Bilangan $\Re_{0}$ adalah parameter ambang untuk kestabilan lokal dari titik ekuilibrium bebas penyakit. Menurut (Dreissche dan Watnough, 2002), apabila bilangan $\Re_{0}<1$, maka titik ekuilibrium bebas penyakit $\left(x^{*}\right)$ dikatakan stabil asimtotik lokal. Apabila bilangan $\Re_{0}>1$, maka titik ekuilibrium bebas penyakit $\left(x^{*}\right)$ dikatakan tidak stabil. 
Analisis Penyebaran Penyakit Covid-19 dengan Pengaruh Pengobatan Isolasi Mandiri dan Pengobatan...

\section{METODE PENELITIAN}

\section{Metode}

Metode penelitian yang digunakan pada tulisan ini menggunakan kajian pustaka dengan mengumpulkan literatur bacaan berupa jurnal, buku teks, artikel ilmiah, dan tulisan lain yang mendukung skripsi ini.

\section{Sumber Data}

Data yang mendukung penelitian ini adalah berupa data sekunder. Data tersebut diumumkan oleh Pemerintah Provinsi DKI Jakarta pada website www.corona.jakarta.go.id.

\section{Tahapan Penelitian}

1. Membangun model penyebaran penyakit Covid-19 dengan pengaruh pengobatan isolasi mandiri dan pengobatan perawatan rumah sakit. Hal yang bisa dilakukan adalah mengasumsikan variabel dan parameter pada model, menggambar diagram transfer model penyebaran, dan membentuk sistem persamaan diferensial model.

2. Mengkaji model yang telah dibuat. Hal yang bisa dilakukan adalah menulis model dalam bentuk non-dimensional, menentukan titik keseimbangan (ekuilibrium) bebas penyakit dan endemik dari sistem,

3. Menguji model yang telah dibuat. Hal ini dilakukan agar model dapat dengan benar dan tepat menggambarkan penyebaran penyakit.

4. Menganalisis model yang telah dibuat. Hal yang akan dilakukan adalah melakukan analisis kestabilan pada titik ekuilibrium bebas penyakit, yaitu dengan menemukan matriks generasi selanjutnya. Kemudian menentukan bilangan reproduksi dasar dari matriks generasi selanjutnya.

5. Melakukan simulasi. Simulasi dilakukan dengan memanfaatkan data penyebaran Covid-19 dengan studi kasus di DKI Jakarta untuk melihat bagaimana penyebaran penyakit dalam beberapa waktu ke depan.

\section{PEMBAHASAN}

\section{Membentuk model}

Populasi keseluruhan $(N)$ dibagi menjadi beberapa kompartemen. Penentuan kompartemen atau subpopulasi pada model mengacu pada data penyebaran Covid-19 di Provinsi DKI Jakarta agar realistis. Kompartemen susceptible $(S)$ berisi individu-individu yang rentan terkena penyakit. Kompartemen exposed $(E)$ berisi individu-individu yang terpapar sebaran penyakit namun belum menunjukkan tanda-tanda mengidap penyakit dan belum dapat menularkan penyakit. Kompartemen exposed berisi individu yang sedang dalam masa inkubasi virus SARS-CoV-2. Kompartemen asymptomatically infectious $(A)$ berisi individu-individu yang dapat menularkan penyakit namun tubuhnya tidak menunjukkan gejala terinfeksi. Kompartemen symptomatically infectious (I) berisi individu-individu yang dapat menularkan penyakit dan tubuhnya menunjukkan gejala terinfeksi. Kompartemen treatment berisi individu-individu yang sedang menjalani pengobatan. Kompartemen treatment dipisah menjadi dua, yaitu isolasi mandiri $\left(T_{1}\right)$, dan perawatan rumah sakit $\left(T_{2}\right)$. Kompartemen recovered berisi individu-individu yang sudah sembuh akibat penyakit Covid-19.

Asumsi-asumsi yang akan diterapkan pada model matematika untuk penyebaran penyakit Covid19 ini terdiri sebagai berikut:

1. Penyebab penyakit Covid-19 adalah virus SARS-CoV-2.

2. Diasumsikan populasi tertutup, yaitu tidak ada migrasi ke dalam atau keluar. Jumlah individu dalam populasi konstan.

3. Diasumsikan populasi bercampur secara homogen, yaitu setiap individu dapat melakukan kontak dengan individu lain dengan peluang yang sama. 
4. Diasumsikan ada masa inkubasi untuk individu yang terpapar virus SARS-CoV-2. Individuindividu yang terpapar tidak menyebarkan virus sampai dengan masa inkubasi selesai.

5. Diasumsikan individu-individu dari kompartemen asymptomatic infectious hanya bisa menjalani isolasi mandiri karena penyakit yang diderita tidaklah berat.

6. Diasumsikan individu-individu dari kompartemen symptomatic infectious dapat menjalani isolasi mandiri atau perawatan rumah sakit bergantung dengan keparahan penyakit yang dialami.

7. Diasumsikan tingkat kematian akibat penyakit Covid-19 untuk subpopulasi isolasi mandiri dan subpopulasi perawatan rumah sakit bernilai sama. Dikarenakan subpopulasi isolasi mandiri juga mendapat perhatian dari lembaga kesehatan untuk penyembuhannya, serupa dengan subpopulasi perawatan rumah sakit.

Dengan demikian dibentuk model transfer sebagai berikut:

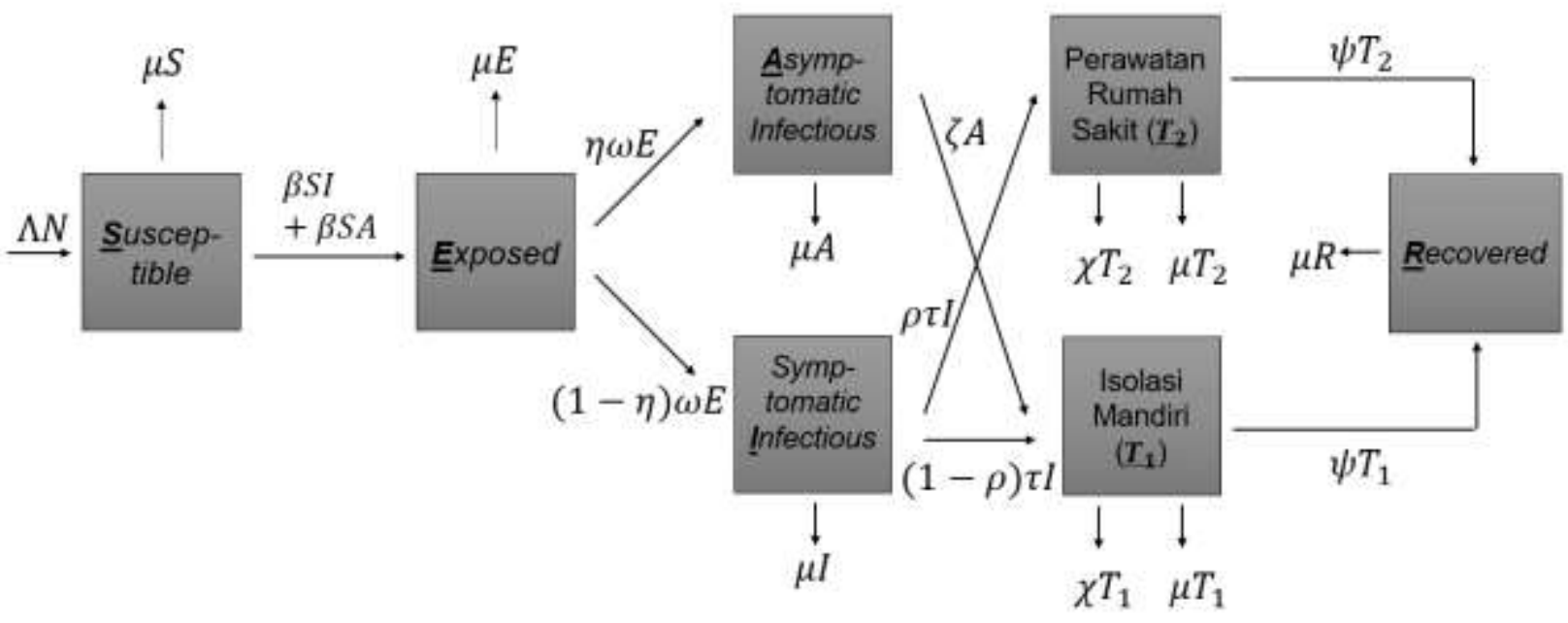

GAMBAR 1. Diagram Transfer Antar Kompartemen/Subpopulasi

Parameter $\Lambda$ dan $\mu$ berturut-turut mewakili laju kelahiran alami dan laju kematian alami. Laju penyebaran virus SARS-CoV-2 diwakili oleh parameter $\beta$. Durasi masa inkubasi individu rentan terpapar menjadi infectious diwakilkan oleh parameter $1 / \omega$. Proporsi individu rentan terpapar yang akan menjadi individu infectious diwakilkan oleh parameter $\eta$. Parameter $\chi$ dan $\psi$ berturut-turut mewakili laju kematian akibat Covid-19 dan laju sembuh dari Covid-19. Parameter $\tau$ dan $\zeta$ berturutturut mewakili laju individu kompartemen $I$ mendapatkan treatment dan laju individu kompartemen $A$ mendapatkan treatment. Proporsi individu kompartemen $I$ yang menjalani perawatan rumah sakit diwakilkan parameter $\rho$. Berikut system persamaan diferensial masing-masing kompartemen:

$$
\begin{aligned}
& \frac{d S}{d t}=\Lambda N-(\beta S I+\beta S A)-\mu S \\
& \frac{d E}{d t}=\beta S I+\beta S A-\eta \omega E-(1-\eta) \omega E-\mu E \\
& \frac{d A}{d t}=\eta \omega E-\zeta A-\mu A \\
& \frac{d I}{d t}=(1-\eta) \omega E-\rho \tau I-(1-\rho) \tau I-\mu I \\
& \frac{d T_{1}}{d t}=\zeta A+(1-\rho) \tau I-\chi T_{1}-\mu T_{1}-\psi T_{1} \\
& \frac{d T_{2}}{d t}=\rho \tau I-\chi T_{2}-\mu T_{2}-\psi T_{2} \\
& \frac{d R}{d t}=\psi T_{1}+\psi T_{2}-\mu R
\end{aligned}
$$


dengan nilai $N=S+E+A+I+T_{1}+T_{2}+R$, maka $\frac{d N}{d t}=0$.

\section{Mengkaji model}

Sistem persamaan diferensial model dibentuk dalam model non-dimensional untuk penyederhanaan, proporsi banyaknya individu masing-masing kompartemen dapat dinyatakan sebagai berikut:

$$
\begin{aligned}
& \frac{d s}{d t}=\Lambda-(\beta s i+\beta s a)-\mu s \\
& \frac{d e}{d t}=\beta s i+\beta s a-\eta \omega e-(1-\eta) \omega e-\mu e \\
& \frac{d a}{d t}=\eta \omega e-\zeta a-\mu a \\
& \frac{d i}{d t}=(1-\eta) \omega e-\rho \tau i-(1-\rho) \tau i-\mu i \\
& \frac{d t_{1}}{d t}=\zeta a+(1-\rho) \tau i-\chi t_{1}-\mu t_{1}-\psi t_{1} \\
& \frac{d t_{2}}{d t}=\rho \tau i-\chi t_{2}-\mu t_{2}-\psi t_{2} \\
& \frac{d r}{d t}=\psi t_{1}+\psi t_{2}-\mu r
\end{aligned}
$$

dengan $\quad s=\frac{S}{N}, \quad e=\frac{E}{N}, \quad a=\frac{A}{N}, \quad i=\frac{I}{N}, \quad t_{1}=\frac{T_{1}}{N}, \quad t_{2}=\frac{T_{2}}{N}, \quad r=\frac{R}{N}, \quad v=\frac{V}{N}, \quad$ dan $s+e+a+i+t_{1}+t_{2}+r+v=\frac{N}{N}=1$.

Kemudian sistem persamaan diferensial dari model dicari titik ekuilibriumnya. Berdasarkan (Banerjee, 2014), sistem persamaan diferensial ditulis dalam bentuk sama dengan nol untuk mencari titik ekuilibrium bebas penyakit dan titik ekuilibirum endemik.

$$
\begin{gathered}
\Lambda-(\beta s i+\beta s a)-\mu s=0 \\
\beta s i+\beta s a-\eta \omega e-(1-\eta) \omega e-\mu e=0 \\
\eta \omega e-\zeta a-\mu a=0 \\
(1-\eta) \omega e-\rho \tau i-(1-\rho) \tau i-\mu i=0 \\
\zeta a+(1-\rho) \tau i-\chi t_{1}-\mu t_{1}-\psi t_{1}=0 \\
\rho \tau i-\chi t_{2}-\mu t_{2}-\psi t_{2}=0 \\
\psi t_{1}+\psi t_{2}-\mu r=0
\end{gathered}
$$

a. Titik ekuilibrium bebas penyakit

Titik ekuilibrium bebas penyakit didapatkan ketika $a=0$ dan $i=0$ dikarenakan tidak adanya subpopulasi yang terinfeksi. Dengan mensubstitusi $a=0=i$, maka

$$
\begin{gathered}
\Lambda-\mu s=0 \\
-\eta \omega e-(1-\eta) \omega e-\mu e=0 \\
\eta \omega e=0
\end{gathered}
$$




$$
\begin{gathered}
(1-\eta) \omega e=0 \\
-\chi t_{1}-\mu t_{1}-\psi t_{1}=0 \\
-\chi t_{2}-\mu t_{2}-\psi t_{2}=0 \\
\psi t_{1}+\psi t_{2}-\mu r=0 .
\end{gathered}
$$

Didapatkan titik ekuilibrium bebas penyakit

$$
E_{1}\left(s, e, a, i, t_{1}, t_{2}, r\right)=\left(\frac{\Lambda}{\mu}, 0,0,0,0,0,0\right)
$$

b. Titik ekuilibrium endemik

Titik ekuilibrium endemik didapatkan ketika $a>0$ dan $i>0$ dikarenakan adanya subpopulasi yang terinfeksi.

$$
\begin{gathered}
\Lambda-(\beta s i+\beta s a)-\mu s=0 \\
\beta s i+\beta s a-\eta \omega e-(1-\eta) \omega e-\mu e=0 \\
\eta \omega e-\zeta a-\mu a=0 \\
(1-\eta) \omega e-\rho \tau i-(1-\rho) \tau i-\mu i=0 \\
\zeta a+(1-\rho) \tau i-\chi t_{1}-\mu t_{1}-\psi t_{1}=0 \\
\rho \tau i-\chi t_{2}-\mu t_{2}-\psi t_{2}=0 \\
\psi t_{1}+\psi t_{2}-\mu r=0
\end{gathered}
$$

Dari persamaan $\beta s i+\beta s a-\eta \omega e-(1-\eta) \omega e-\mu e=0$, didapatkan $s=\frac{(\mu+\omega) e}{\beta i+\beta a}$.

Dari persamaan $\eta \omega e-\zeta a-\mu a=0$, didapatkan $a=\frac{\eta \omega e}{\mu+\zeta}$.

Dari persamaan $(1-\eta) \omega e-\rho \tau i-(1-\rho) \tau i-\mu i=0$, didapatkan $i=\frac{e(\omega-\eta \omega)}{\mu+\tau}$

Substitusi $a=\frac{\eta \omega e}{\mu+\zeta}$ dan $i=\frac{e(\omega-\eta \omega)}{\mu+\tau}$ ke dalam $s=\frac{(\mu+\omega) e}{\beta i+\beta a}$, didapatkan titik ekuilibrium endemik dari kompartemen $S$ yaitu $s^{*}=\frac{(\mu+\omega)(\mu+\tau)(\mu+\zeta)}{\beta(\omega-\eta \omega)+(\mu+\zeta)+\beta \eta \omega(\mu+\tau)}$.

Dari persamaan $\beta s i+\beta s a-\eta \omega e-(1-\eta) \omega e-\mu e=0$, didapatkan $e=\frac{\beta s i+\beta s a}{\mu+\omega}$.

Substitusi $e=\frac{\beta s i+\beta s a}{\mu+\omega}$ ke dalam $\eta \omega e-\zeta a-\mu a=0$, didapatkan $a=\frac{\eta \omega \beta s i}{(\mu+\zeta)(\omega+\mu)-\eta \omega \beta s}$.

Substitusi $\quad a=\frac{\eta \omega \beta s i}{(\mu+\zeta)(\omega+\mu)-\eta \omega \beta s} \quad$ ke dalam $\Lambda-(\beta s i+\beta s a)-\mu s=0$, didapatkan titik ekuilibrium endemik dari kompartemen $I$ yaitu $i^{*}=\frac{\Lambda-\mu s^{*}}{\beta s^{*}}-\frac{\left(\Lambda-\mu s^{*}\right) \eta \omega}{(\mu+\zeta)(\omega+\mu)}$.

Pada persamaan $(1-\eta) \omega e-\rho \tau i-(1-\rho) \tau i-\mu i=0$, masukkan $e=\frac{\beta s i+\beta s a}{\mu+\omega}$, didapatkan $i=\frac{-\omega \beta s a+\eta \omega \beta s a}{\omega \beta s-\eta \omega \beta s-(\mu+\tau)(\mu+\omega)}$.

Substitusi $i=\frac{-\omega \beta s a+\eta \omega \beta s a}{\omega \beta s-\eta \omega \beta s-(\mu+\tau)(\mu+\omega)}$ ke dalam $\Lambda-(\beta s i+\beta s a)-\mu s=0$, didapatkan titik ekuilibrium endemik dari kompartemen $A$ yaitu $a^{*}=\frac{(-1+\eta) \omega\left(\Lambda-\mu s^{*}\right)}{(\mu+\tau)(\mu+\omega)}+\frac{\Lambda-\mu s^{*}}{\beta s^{*}}$.

Dari persamaan $\beta s i+\beta s a-\eta \omega e-(1-\eta) \omega e-\mu e=0$, didapatkan $e^{*}=\frac{\beta s^{*} i^{*}+\beta s^{*} a^{*}}{\mu+\omega}$.

Dari persamaan $\zeta a+(1-\rho) \tau i-\chi t_{1}-\mu t_{1}-\psi t_{1}=0$, didapatkan $t_{1}^{*}=\frac{\zeta a^{*}+(1-\rho) \tau i^{*}}{\chi+\psi+\mu}$. 
Dari persamaan $\rho \tau i-\chi t_{2}-\mu t_{2}-\psi t_{2}=0$, didapatkan $t_{2}^{*}=\frac{\rho \tau i^{*}}{\chi+\psi+\mu}$.

Dari persamaan $\psi t_{1}+\psi t_{2}-\mu r=0$, didapatkan $r^{*}=\frac{\psi t_{1}^{*}+\psi t_{2}^{*}}{\mu}$.

Dengan demikian didapatkan titik ekuilibirium endemik $E_{2}\left(s^{*}, e^{*}, a^{*}, i^{*}, t_{1}^{*}, t_{2}^{*}, r^{*}\right)$ sebagai berikut:

$$
\begin{gathered}
s^{*}=\frac{(\mu+\omega)(\mu+\tau)(\mu+\zeta)}{\beta(\omega-\eta \omega)+(\mu+\zeta)+\beta \eta \omega(\mu+\tau)} \\
a^{*}=\frac{\beta s^{*} i^{*}+\beta s^{*} a^{*}}{\mu+\omega} \\
i^{*}=\frac{(-1+\eta) \omega\left(\Lambda-\mu s^{*}\right)}{\beta-\mu s^{*}}-\frac{(\mu+\omega)}{\beta s^{*}}-\frac{\left(\Lambda-\mu s^{*}\right) \eta \omega}{\beta s^{*}} \\
t_{1}^{*}=\frac{\zeta a^{*}+(1-\rho)(\omega+\mu)}{\chi+\psi+\mu} \\
t_{2}^{*}=\frac{\rho \tau i^{*}}{\chi+\psi+\mu} \\
r^{*}=\frac{\psi t_{1}^{*}+\psi t_{2}^{*}}{\mu}
\end{gathered}
$$

\section{Menguji model}

Model akan diuji dengan daftar asumsi A(1)-A(5) dari (Driessche dan Watnough, 2002). Sebelum model akan diuji dengan A(1)-A(5), model akan dibentuk dalam model transmisi penyakit sebagai berikut:

$$
\begin{aligned}
& f_{i}(x)=\mathcal{F}_{i}(x)-\nu_{i}(x) \\
& f_{i}(x)=\mathcal{F}_{i}(x)-\left(v_{i}^{-}(x)-v_{i}^{+}(x)\right) \\
& \left.\left(\begin{array}{l}
f_{1}(x) \\
f_{2}(x) \\
f_{3}(x) \\
f_{4}(x) \\
f_{5}(x) \\
f_{6}(x) \\
f_{7}(x)
\end{array}\right)=\left(\begin{array}{l}
\mathcal{F}_{1}(x) \\
\mathcal{F}_{2}(x) \\
\mathcal{F}_{3}(x) \\
\mathcal{F}_{4}(x) \\
\mathcal{F}_{5}(x) \\
\mathcal{F}_{6}(x) \\
\mathcal{F}_{7}(x)
\end{array}\right)-\left[\begin{array}{c}
v_{1}^{-}(x) \\
v_{2}^{-}(x) \\
v_{3}^{-}(x) \\
v_{4}^{-}(x) \\
v_{5}^{-}(x) \\
v_{6}^{-}(x) \\
v_{7}^{-}(x)
\end{array}\right)-\left(\begin{array}{l}
v_{1}^{+}(x) \\
v_{2}^{+}(x) \\
v_{3}^{+}(x) \\
v_{4}^{+}(x) \\
v_{5}^{+}(x) \\
v_{6}^{+}(x) \\
v_{7}^{+}(x)
\end{array}\right)\right] \\
& \left(\begin{array}{c}
d e / d t \\
d a / d t \\
d i / d t \\
d t_{1} / d t \\
d t_{2} / d t \\
d s / d t \\
d r / d t
\end{array}\right)=\left(\begin{array}{c}
\beta s i+\beta s a \\
0 \\
0 \\
0 \\
0 \\
0 \\
0
\end{array}\right)-\left[\left(\begin{array}{c}
{[\eta \omega+(1-\eta) \omega+\mu] e} \\
(\mu+\zeta) a \\
{[\rho \tau+(1-\rho) \tau+\mu] i} \\
(\chi+\psi+\mu) t_{1} \\
(\chi+\psi+\mu) t_{2} \\
(\beta i+\beta a+\mu) s \\
(\mu) r
\end{array}\right)-\left(\begin{array}{c}
0 \\
\eta \omega e \\
(1-\eta) \omega e \\
\zeta a+(1-\rho) \tau i \\
\rho \tau i \\
\Lambda \\
\psi t_{1}+\psi t_{2}
\end{array}\right)\right]
\end{aligned}
$$

Setelah menulis ulang model dalam model transmisi penyakit, model akan diuji dengan asumsiasumsi A(1)-A(5). Berikut bunyi dari A(1)-A(5) beserta analisisnya:

A(1) Jika $x \geq 0$, maka $\mathcal{F}_{i}, v_{i}^{+}, v_{i}^{-} \geq 0$ for $i=1, \ldots, n$.

Analisis: Variabel $x$ adalah himpunan individu secara keseluruhan dalam populasi. Pada kompartemen ke-i untuk $i=1,2, \ldots, 7$, jumlah individunya pastilah non-negatif $(\geq 0)$, sehingga tingkat adanya infeksi baru pada kompartemen ke- $i\left(\mathcal{F}_{i}\right)$ non-negatif, tingkat perpindahan individu menuju kompartemen ke- $i\left(\mathcal{V}_{i}^{+}\right)$non-negatif, dan tingkat perpindahan individu yang keluar dari kompartemen ke- $i\left(\mathcal{V}_{i}^{-}\right)$juga non-negatif.

A(2) Jika $x_{i}=0$ maka $\nu_{i}^{-}=0$. Secara khusus, jika $x \in X_{s}$, maka $\nu_{i}^{-}=0$ untuk $i=1, \ldots, m$. 
Analisis: Variabel $x_{i}=0$ adalah jumlah individu pada kompartemen ke- $i$, untuk $i=1,2, \ldots, 7$. Tingkat $\mathcal{V}_{i}^{-}$adalah tingkat perpindahan individu keluar dari kompartemen ke- $i$. Jika jumlah individu pada kompartemen ke- $i$ bernilai nol, maka benar tidak ada individu yang keluar dari kompartemen ke- $i$. Kemudian jika populasi keseluruhan berada dalam keadaan bebas penyakit yaitu $x \in X_{s}$, maka pada kompartemen $A$ dan $I$ bernilai nol sehingga tidak ada perpindahan individu.

$\mathbf{A}(\mathbf{3}) \mathcal{F}_{i}=0$ jika $i>m$.

Analisis: Diketahui populasi keseluruhan ada 7 kompartemen $\left(E, A, I, T_{1}, T_{2}, S\right.$, dan $R$ ) sehingga $i=1,2, \ldots, 7$. Kompartemen berisi individu terinfeksi adalah kompartemen $E, A, I, T_{1}$, dan $T_{2}$ sehingga $m=1,2, \ldots, 5$. Untuk kompartemen $i>m$ adalah $i=6,7$ yaitu kompartemen $S$ dan $R$. Diketahui $\mathcal{F}_{6}=0$ dan $\mathcal{F}_{7}=0$, maka (A3) terpenuhi.

A(4) Jika $x \in X_{s}$, maka $\mathcal{F}_{i}(x)=0$ dan $\nu_{i}^{+}(x)=0$ untuk $i=1, \ldots, m$.

Analisis: Jika populasi keseluruhan dalam keadaan bebas penyakit $\left(x \in X_{s}\right)$, maka $\mathcal{F}_{i}(x)$ dan $\mathcal{V}_{i}^{+}$ untuk $i=1, \ldots, 5$ bernilai nol karena bebas penyakit $(I=0$ dan $A=0)$.

A(5) Jika $\mathcal{F}$ bernilai nol, maka seluruh nilai eigen dari $D f\left(x^{*}\right)$ mempunyai bagian riil negatif. $D f\left(x^{*}\right)$ adalah turunan dari $\frac{\partial f_{i}}{\partial x_{i}}$ yang dihitung pada titik keseimbangan bebas penyakit, $x^{*}$ (yaitu matriks Jacobian).

Analisis: Substitusi $\mathcal{F}=0$ ke dalam $f_{i}(x)=\mathcal{F}_{i}(x)-\left(\mathcal{V}_{i}^{-}(x)-\mathcal{V}_{i}^{+}(x)\right)$

$$
\begin{aligned}
& f_{i}(x)=\mathcal{F}_{i}(x)-\left(\mathcal{V}_{i}^{-}(x)-v_{i}^{+}(x)\right) \\
& f_{i}(x)=0-\left(v_{i}^{-}(x)-v_{i}^{+}(x)\right) \\
& f_{i}(x)=-\left(\mathcal{V}_{i}^{-}(x)-v_{i}^{+}(x)\right) \\
& f_{i}(x)=-\left(\left(\begin{array}{c}
{[\eta \omega+(1-\eta) \omega+\mu] e} \\
(\mu+\zeta) a \\
{[\rho \tau+(1-\rho) \tau+\mu] i} \\
(\chi+\psi+\mu) t_{1} \\
(\chi+\psi+\mu) t_{2} \\
(\beta i+\beta a+\mu) s \\
(\mu) r
\end{array}\right)-\left(\begin{array}{c}
0 \\
\eta \omega e \\
(1-\eta) \omega e \\
\zeta a+(1-\rho) \tau i \\
\rho \tau i \\
\Lambda \\
\psi t_{1}+\psi t_{2}
\end{array}\right)\right) \\
& f_{i}(x)=\left(\begin{array}{c}
-\left(\eta \omega+a_{j} \omega+\mu\right) e \\
-(\mu+\zeta) a+\eta \omega e \\
-\left(\rho \tau+b_{j} \tau+\mu\right) i+a_{j} \omega e \\
-(\chi+\psi+\mu) t_{1}+\zeta a+b_{j} \tau i \\
-(\chi+\psi+\mu) t_{2}+\rho \tau i \\
-(\beta i+\beta a+\mu) s+\Lambda \\
-\mu r+\psi t_{1}+\psi t_{2}
\end{array}\right)
\end{aligned}
$$

dengan $a_{j}=1-\eta$ dan $b_{j}=1-\rho$.

Maka matriks Jacobian dari $f_{i}(x)$ adalah

$$
J\left(f_{i}(x)\right)=\left[\begin{array}{ccccccc}
-p_{j} & 0 & 0 & 0 & 0 & 0 & 0 \\
\eta \omega & -q_{j} & 0 & 0 & 0 & 0 & 0 \\
a_{j} \omega & 0 & -r_{j} & 0 & 0 & 0 & 0 \\
0 & \zeta & b_{j} \tau & -s_{j} & 0 & 0 & 0 \\
0 & 0 & \rho \tau & 0 & -s_{j} & 0 & 0 \\
0 & -\beta s & -\beta s & 0 & 0 & -(\mu+\beta i+\beta a) & 0 \\
0 & 0 & 0 & \psi & \psi & 0 & -\mu
\end{array}\right]
$$

dengan $p_{j}=a_{j} \omega+\eta \omega+\mu, q_{j}=\mu+\zeta, r_{j}=b_{j} \tau+\rho \tau+\mu$, dan $s_{j}=\chi+\psi+\mu$. 
Kemudian dibentuk persamaan karakteristik $\operatorname{det}\left(\lambda I-J\left(f_{i}(x)\right)\right)=0$,

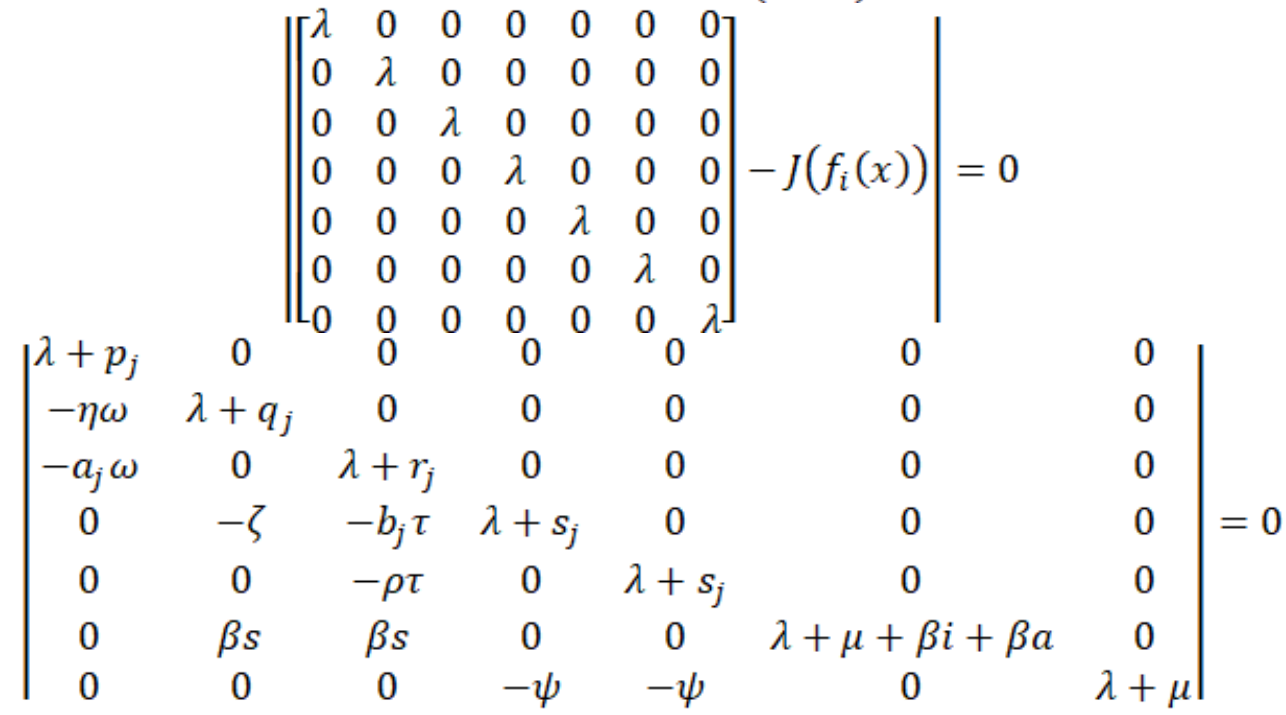

dengan $p_{j}=\eta \omega+a_{j} \omega+\mu, q_{j}=\mu+\zeta, r_{j}=\rho \tau+b_{j} \tau+\mu$, dan $s_{j}=\chi+\psi+\mu$.

Substitusi titik ekuilibrium bebas penyakit $s=\frac{\Lambda}{\mu}, a=0$ dan $i=0$. Didapatkan

$$
\left|\begin{array}{ccccccc}
\lambda+p_{j} & 0 & 0 & 0 & 0 & 0 & 0 \\
-\eta \omega & \lambda+q_{j} & 0 & 0 & 0 & 0 & 0 \\
-a_{j} \omega & 0 & \lambda+r_{j} & 0 & 0 & 0 & 0 \\
0 & -\zeta & -b_{j} \tau & \lambda+s_{j} & 0 & 0 & 0 \\
0 & 0 & -\rho \tau & 0 & \lambda+s_{j} & 0 & 0 \\
0 & \frac{\beta \Lambda}{\mu} & \frac{\beta \Lambda}{\mu} & 0 & 0 & \lambda+\mu & 0 \\
0 & 0 & 0 & -\psi & -\psi & 0 & \lambda+\mu
\end{array}\right|=0
$$

$\left(\lambda+a_{j} \omega+\eta \omega+\mu\right)(\lambda+\mu+\zeta)\left(\lambda+b_{j} \tau+\rho \tau+\mu\right)(\lambda+\chi+\psi+\mu)^{2}(\lambda+\mu)^{2}=0$.

Didapatkan: $\lambda_{1}=-\mu-\zeta, \lambda_{2}=-a_{j} \omega-\eta \omega-\mu, \lambda_{3}=-b_{j} \tau-\rho \tau-\mu, \lambda_{4}=-\mu, \lambda_{5}=-\mu$, $\lambda_{6}=-\chi-\psi-\mu$, dan $\lambda_{7}=-\chi-\psi-\mu$.

Dikarenakan semua nilai eigen bernilai negatif, maka dapat diartikan tidak ada interaksi-interaksi, maka dapat disimpulkan tingkat adanya infeksi baru $(\mathcal{F})$ bernilai 0 . Berdasarkan asumsi-asumsi A(1)-A(5), model memenuhi semua asumsi, sehingga model dapat digunakan untuk analisis.

\section{Menganalisis model}

Diketahui bahwa matriks tingkat munculnya infeksi baru dari model adalah

$$
\mathcal{F}_{i}\left(x^{*}\right)=\left(\begin{array}{c}
\beta s i+\beta s a \\
0 \\
0 \\
0 \\
0 \\
0 \\
0
\end{array}\right)
$$

Matriks $F$ didapat dari 


$$
\begin{aligned}
F=\frac{\partial \mathcal{F}_{i}}{\partial x_{J}}\left(x^{*}\right)= & =\left[\begin{array}{llllll}
\frac{\partial \mathcal{F}_{1}}{\partial x_{1}} & \frac{\partial \mathcal{F}_{1}}{\partial x_{2}} & \frac{\partial \mathcal{F}_{1}}{\partial x_{3}} & \frac{\partial \mathcal{F}_{1}}{\partial x_{4}} & \frac{\partial \mathcal{F}_{1}}{\partial x_{5}} \\
\frac{\partial \mathcal{F}_{2}}{\partial x_{1}} & \frac{\partial \mathcal{F}_{2}}{\partial x_{2}} & \frac{\partial \mathcal{F}_{2}}{\partial x_{3}} & \frac{\partial \mathcal{F}_{2}}{\partial x_{4}} & \frac{\partial \mathcal{F}_{2}}{\partial x_{5}} \\
\frac{\partial \mathcal{F}_{3}}{\partial x_{1}} & \frac{\partial \mathcal{F}_{3}}{\partial x_{2}} & \frac{\partial \mathcal{F}_{3}}{\partial x_{3}} & \frac{\partial \mathcal{F}_{3}}{\partial x_{4}} & \frac{\partial \mathcal{F}_{3}}{\partial x_{5}} \\
\frac{\partial \mathcal{F}_{4}}{\frac{\partial x_{1}}{\partial \mathcal{F}_{4}}} & \frac{\partial \mathcal{F}_{4}}{\partial x_{2}} & \frac{\partial \mathcal{F}_{4}}{\partial x_{3}} & \frac{\partial \mathcal{F}_{4}}{\partial x_{4}} & \frac{\partial \mathcal{F}_{4}}{\partial x_{5}} \\
\frac{\partial \mathcal{F}_{5}}{\partial x_{1}} & \frac{\partial \mathcal{F}_{5}}{\partial x_{2}} & \frac{\partial \mathcal{F}_{5}}{\partial x_{3}} & \frac{\partial \mathcal{F}_{5}}{\partial x_{4}} & \frac{\partial \mathcal{F}_{5}}{\partial x_{5}}
\end{array}\right]=\left[\begin{array}{cccccc}
\frac{\partial \mathcal{F}_{1}}{\partial e} & \frac{\partial \mathcal{F}_{1}}{\partial a} & \frac{\partial \mathcal{F}_{1}}{\partial i} & \frac{\partial \mathcal{F}_{1}}{\partial t_{1}} & \frac{\partial \mathcal{F}_{1}}{\partial t_{2}} \\
\frac{\partial \mathcal{F}_{2}}{\partial e} & \frac{\partial \mathcal{F}_{2}}{\partial a} & \frac{\partial \mathcal{F}_{2}}{\partial i} & \frac{\partial \mathcal{F}_{2}}{\partial t_{1}} & \frac{\partial \mathcal{F}_{2}}{\partial t_{2}} \\
\frac{\partial \mathcal{F}_{3}}{\partial e} & \frac{\partial \mathcal{F}_{3}}{\partial a} & \frac{\partial \mathcal{F}_{3}}{\partial i} & \frac{\partial \mathcal{F}_{3}}{\partial t_{1}} & \frac{\partial \mathcal{F}_{3}}{\partial t_{2}} \\
\frac{\partial \mathcal{F}_{4}}{\partial e} & \frac{\partial \mathcal{F}_{4}}{\partial a} & \frac{\partial \mathcal{F}_{4}}{\partial i} & \frac{\partial \mathcal{F}_{4}}{\partial t_{1}} & \frac{\partial \mathcal{F}_{4}}{\partial t_{2}} \\
\frac{\partial \mathcal{F}_{5}}{\partial e} & \frac{\partial \mathcal{F}_{5}}{\partial a} & \frac{\partial \mathcal{F}_{5}}{\partial i} & \frac{\partial \mathcal{F}_{5}}{\partial t_{1}} & \frac{\partial \mathcal{F}_{5}}{\partial t_{2}}
\end{array}\right] \\
= & =\left[\begin{array}{llllll}
0 & \beta s & \beta s & 0 & 0 \\
0 & 0 & 0 & 0 & 0 \\
0 & 0 & 0 & 0 & 0 \\
0 & 0 & 0 & 0 & 0 \\
0 & 0 & 0 & 0 & 0
\end{array}\right]
\end{aligned}
$$

Substitusi titik $x^{*}$, maka

$$
F=\left[\begin{array}{ccccc}
0 & \frac{\beta \Lambda}{\mu} & \frac{\beta \Lambda}{\mu} & 0 & 0 \\
0 & 0 & 0 & 0 & 0 \\
0 & 0 & 0 & 0 & 0 \\
0 & 0 & 0 & 0 & 0 \\
0 & 0 & 0 & 0 & 0
\end{array}\right]
$$

Diketahui dari matriks transmisi penyakit,

$$
v_{i}\left(x^{*}\right)=\left[\begin{array}{c}
\left(\eta \omega+a_{j} \omega+\mu\right) e \\
(\mu+\zeta) a-\eta \omega e \\
\left(\rho \tau+b_{j} \tau+\mu\right) i-a_{j} \omega e \\
(\chi+\psi+\mu) t_{1}-\zeta a-b_{j} \tau i \\
(\chi+\psi+\mu) t_{2}-\rho \tau i \\
(\beta i+\beta a+\mu) s-\Lambda \\
\mu r-\psi t_{1}-\psi t_{2}
\end{array}\right]
$$

dengan $a_{j}=(1-\eta)$ dan $b_{j}=(1-\rho)$. Maka

$$
V=\left[\begin{array}{lllll}
\frac{\partial v_{1}}{\partial e} & \frac{\partial v_{1}}{\partial a} & \frac{\partial v_{1}}{\partial i} & \frac{\partial v_{1}}{\partial t_{1}} & \frac{\partial v_{1}}{\partial t_{2}} \\
\frac{\partial v_{2}}{\partial e} & \frac{\partial v_{2}}{\partial a} & \frac{\partial v_{2}}{\partial i} & \frac{\partial v_{2}}{\partial t_{1}} & \frac{\partial v_{2}}{\partial t_{2}} \\
\frac{\partial v_{3}}{\partial e} & \frac{\partial v_{3}}{\partial a} & \frac{\partial v_{3}}{\partial i} & \frac{\partial v_{3}}{\partial t_{1}} & \frac{\partial v_{3}}{\partial t_{2}} \\
\frac{\partial v_{4}}{\partial e} & \frac{\partial v_{4}}{\partial a} & \frac{\partial v_{4}}{\partial i} & \frac{\partial v_{4}}{\partial t_{1}} & \frac{\partial v_{4}}{\partial t_{2}} \\
\frac{\partial v_{5}}{\partial e} & \frac{\partial v_{5}}{\partial a} & \frac{\partial v_{5}}{\partial i} & \frac{\partial v_{5}}{\partial t_{1}} & \frac{\partial v_{5}}{\partial t_{2}}
\end{array}\right]=\left[\begin{array}{ccccc}
p_{j} & 0 & 0 & 0 & 0 \\
-\eta \omega & q_{j} & 0 & 0 & 0 \\
-a_{j} \omega & 0 & r_{j} & 0 & 0 \\
0 & -\zeta & -b_{j} \tau & s_{j} & 0 \\
0 & 0 & -\rho \tau & 0 & s_{j}
\end{array}\right]
$$

dengan $p_{j}=a_{j} \omega+\eta \omega+\mu, q_{j}=\mu+\zeta, r_{j}=b_{j} \tau+\rho \tau+\mu$, dan $s_{j}=\chi+\psi+\mu$.

Invers dari $V$ adalah 


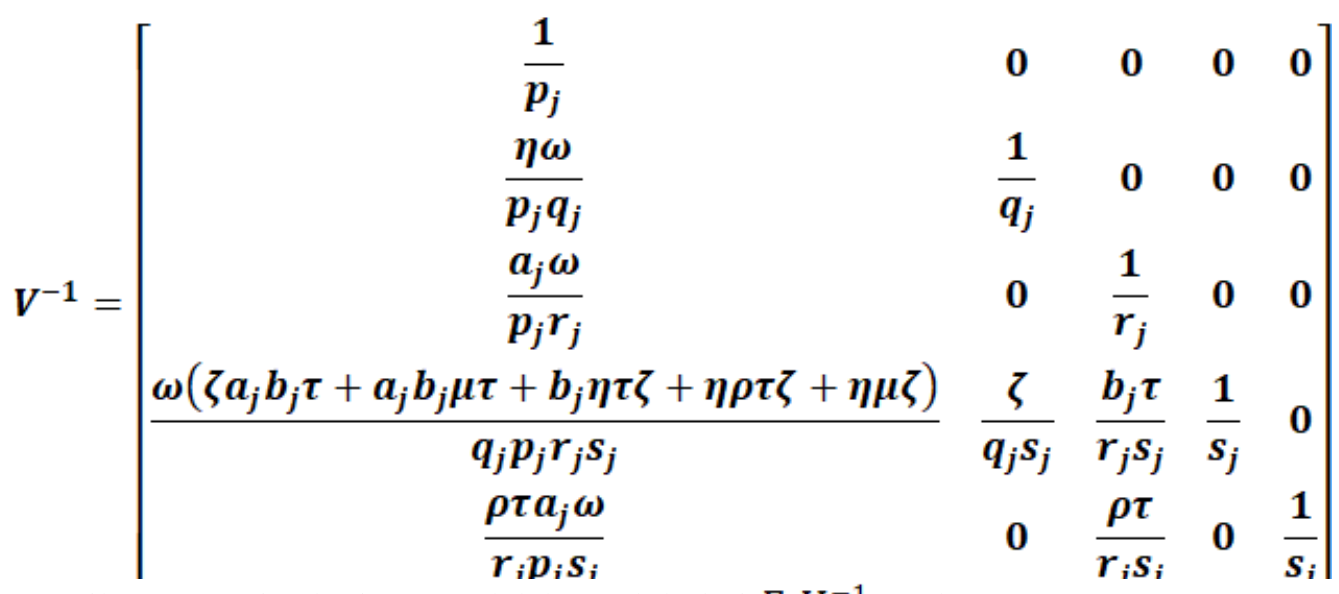

Matriks generasi selanjutnya adalah produk dari $F \cdot V^{-1}$, maka $N G M=F . V^{-1}$

$$
\begin{aligned}
& =\left[\begin{array}{ccccc}
0 & \frac{\beta \Lambda}{\mu} & \frac{\beta \Lambda}{\mu} & 0 & 0 \\
0 & 0 & 0 & 0 & 0 \\
0 & 0 & 0 & 0 & 0 \\
0 & 0 & 0 & 0 & 0 \\
0 & 0 & 0 & 0 & 0
\end{array}\right]\left[\begin{array}{ccccc}
\frac{1}{p_{j}} & 0 & 0 & 0 & 0 \\
\frac{\eta \omega}{p_{j} q_{j}} & \frac{a_{j} \omega}{p_{j} r_{j}} & 0 & 0 & 0 \\
\frac{\omega\left(\zeta a_{j} b_{j} \tau+a_{j} b_{j} \mu \tau+b_{j} \eta \tau \zeta+\eta \rho \tau \zeta+\eta \mu \zeta\right)}{q_{j} p_{j} r_{j} s_{j}} & \frac{\zeta}{q_{j} s_{j}} & \frac{b_{j} \tau}{r_{j} s_{j}} & \frac{1}{s_{j}} & 0 \\
\frac{\rho \tau a_{j} \omega}{r_{j} p_{j} s_{j}} & 0 & \frac{\rho \tau}{r_{j} s_{j}} & 0 & \frac{1}{s_{j}}
\end{array}\right] \\
& N G M=\left[\begin{array}{cccccc}
\frac{\beta \Lambda \eta \omega}{\mu p_{j} q_{j}}+\frac{\beta \Lambda a_{j} \omega}{\mu p_{j} r_{j}} & \frac{\beta \Lambda}{\mu q_{j}} & \frac{\beta \Lambda}{\mu r_{j}} & 0 & 0 \\
0 & 0 & 0 & 0 & 0 \\
0 & 0 & 0 & 0 & 0 \\
0 & 0 & 0 & 0 & 0 \\
0 & 0 & 0 & 0 & 0
\end{array}\right] .
\end{aligned}
$$

Seperti diketahui bilangan reproduksi adalah nilai eigen terbesar dari matriks generasi selanjutnya, maka akan dicari determinan dari persamaan karakteristik $\mathrm{FV}^{-1}$.

$$
\begin{aligned}
\left\|\left[\begin{array}{ccccccc}
\lambda & 0 & 0 & 0 & 0 & 0 & 0 \\
0 & \lambda & 0 & 0 & 0 & 0 & 0 \\
0 & 0 & \lambda & 0 & 0 & 0 & 0 \\
0 & 0 & 0 & \lambda & 0 & 0 & 0 \\
0 & 0 & 0 & 0 & \lambda & 0 & 0 \\
0 & 0 & 0 & 0 & 0 & \lambda & 0 \\
0 & 0 & 0 & 0 & 0 & 0 & \lambda
\end{array}\right]-\left[\begin{array}{ccccc}
\frac{\beta \Lambda \eta \omega}{\mu p_{j} q_{j}}+\frac{\beta \Lambda a_{j} \omega}{\mu p_{j} r_{j}} & \frac{\beta \Lambda}{\mu q_{j}} & \frac{\beta \Lambda}{\mu r_{j}} & 0 & 0 \\
0 & 0 & 0 & 0 & 0 \\
0 & 0 & 0 & 0 & 0 \\
0 & 0 & 0 & 0 & 0 \\
0 & 0 & 0 & 0 & 0
\end{array}\right]\right\|=0 \\
\\
\left(\lambda-\frac{\beta \Lambda \eta \omega}{\mu p_{j} q_{j}}-\frac{\beta \Lambda a_{j} \omega}{\mu p_{j} r_{j}}\right) \lambda^{4}=0
\end{aligned}
$$

Dengan demikian, didapatkan nilai eigen sebagai berikut:

$$
\lambda_{1}=0, \lambda_{2}=0, \lambda_{3}=0, \lambda_{4}=0 \text {, dan } \lambda_{5}=\frac{\beta \Lambda \eta \omega}{\mu p_{j} q_{j}}+\frac{\beta \Lambda a_{j} \omega}{\mu p_{j} r_{j}} \text {. }
$$


Bilangan reproduksi dasar didapatkan dari spectral radius matriks generasi selanjutnya atau nilai eigen terbesar dari NGM.

$$
\begin{gathered}
\Re_{0}=\kappa\left(F V^{-1}\right)=\kappa\left(0,0,0,0, \frac{\beta \Lambda \eta \omega}{\mu p_{j} q_{j}}+\frac{\beta \Lambda a_{j} \omega}{\mu p_{j} r_{j}}\right)=\frac{\beta \Lambda \eta \omega}{\mu p_{j} q_{j}}+\frac{\beta \Lambda a_{j} \omega}{\mu p_{j} r_{j}} \\
\Re_{0}=\frac{\beta \Lambda \eta \omega}{\mu((1-\eta) \omega+\eta \omega+\mu)(\mu+\zeta)}+\frac{\beta(1-\eta) \omega+\eta \omega+\mu)((1-\rho) \tau+\rho \tau+\mu)}{\mu((1-\eta) \omega}
\end{gathered}
$$

\section{Melakukan simulasi terhadap model}

Simulasi dilakukan dengan program Maple 2018 dan memberikan nilai untuk parameter-parameter yang terdapat pada model. Adapun nilai parameter-parameter yang digunakan dalam model akan dijelaskan sebagai berikut:

- Bersumber data dari (BPS Jakarta, 2021), total populasi penduduk Ibukota Jakarta pada tahun 2019 adalah 10.557 .810 dan pada tahun 2020 adalah 10.562.088. Sedangkan angka kelahiran pada tahun 2020 sebanyak 124.154 berdasarkan rilis data dari (Diskominfotik DKI Jakarta, 2021a). Dengan demikian nilai angka kelahiran $(\Lambda)$ adalah

$$
\begin{aligned}
& \Lambda=\frac{\text { Kelahiran } x 1000}{100} \\
& \Lambda=\frac{\frac{124154 \times 1000}{\frac{10.557 .810+10.562 .088}{2}} / 12}{100} \\
& \Lambda=0,00979755 / \text { bulan }
\end{aligned}
$$

- Angka kematian pada tahun 2020 sebanyak 74.310 jiwa berdasarkan rilis data dari (Diskominfotik DKI Jakarta, 2021b). Lalu dikurangi dengan angka kematian akibat Covid-19 s.d. 31 Desember 2020 sebanyak 3.287 jiwa. Oleh karena itu angka kematian alami pada tahun 2020 sebanyak 71.023 jiwa. Dengan demikian angka kematian alami $(\mu)$ adalah

$$
\begin{gathered}
\mu=\frac{\frac{\text { Kematian } x 1000}{\text { Rata }- \text { rata penduduk } 2019-2020} / 12}{100} \\
\mu=\frac{\frac{71023 \times 1000}{\frac{10.557 .810+10.562 .088}{2}} / 12}{100} \\
\mu=0,005605 / \text { bulan }
\end{gathered}
$$

- Jumlah penularan penyakit Covid-19 di DKI Jakarta pada periode Maret 2020 s.d. Agustus 2021 adalah 850.583 berdasarkan data dari (Corona Jakarta, 2021). Dengan periode sebanyak 18 bulan, maka laju penularan penyakit Covid-19 $(\beta)$ adalah

$$
\beta=\frac{850583 / 18}{10562088}=0,00447 / \text { bulan }
$$

- Jumlah pasien yang sembuh dari penyakit Covid-19 di DKI Jakarta pada periode Maret 2020 s.d. Agustus 2021 adalah 830.197 berdasarkan data dari (Corona Jakarta, 2021). Dengan periode sebanyak 18 bulan, maka laju kesembuhan dari Covid-19 $(\psi)$ adalah

$$
\psi=\frac{830197 / 18}{10562088}=0,0043668 / \text { bulan }
$$


- Jumlah pasien yang meninggal dari penyakit Covid-19 di DKI Jakarta pada periode Maret 2020 s.d. Agustus 2021 adalah 13.290 berdasarkan data dari (Corona Jakarta, 2021). Dengan periode sebanyak 18 bulan, maka laju kematian akibat Covid-19 $(\chi)$ adalah

$$
\chi=\frac{13290 / 18}{10562088}=0,0000699 / \text { bulan }
$$

- Dengan mengolah data jumlah pasien Covid-19 yang bergejala dan tidak bergejala pada periode September 2020 s.d. Juli 2021 dari (Corona Jakarta, 2021), didapatkan proporsi pasien yang tidak menunjukkan gejala sebesar $\eta=0,335634$. Dikarenakan $\eta=0,335634$, maka proporsi pasien yang menunjukkan gejala sebesar $(1-\eta)=0,664363$.

- Berdasarkan data pada (WHO, 2020), angka rata-rata masa inkubasi Covid-19 (1/ $\omega$ ) adalah 5 hari atau $\frac{1}{6}$ bulan. Maka nilai parameter $\omega$ adalah

$$
\omega=\frac{1}{\frac{1}{6}} \frac{\text { individu }}{\text { bulan }}=6 \frac{\text { individu }}{\text { bulan }}
$$

- Diolah data angka pasien yang menjalani isolasi mandiri (isoman) dari pasien tak bergejala (kompartemen A). Data yang diolah adalah periode September 2020 s.d. Juli 2021 sesuai dengan data yang tersedia di (Corona Jakarta, 2021).

Didapatkan angka pasien tak bergejala yang menjalani isolasi mandiri sebanyak 259.892 individu. Maka didapatkan parameter $\zeta$ sebesar

$$
\zeta=\frac{259892 / 11}{10562088}=0,002236 / \text { bulan }
$$

- Diolah data angka pasien bergejala yang menjalani isoman dan perawatan rumah sakit. Data yang diolah adalah periode September 2020 s.d. Juli 2021 sesuai dengan data yang tersedia di (Corona Jakarta, 2021).

Didapatkan proporsi pasien bergejala yang menjalani perawatan rumah sakit sebesar $\rho=0,536805$. Demikian sehingga proporsi pasien bergejala yang menjalani isolasi mandiri sebesar $(1-\rho)=0,463194$.

- Diolah data angka pasien yang menjalani pengobatan dari pasien bergejala (kompartemen $I$ ). Data yang diolah adalah periode September 2020 s.d. Juli 2021 sesuai dengan data yang tersedia di (Corona Jakarta, 2021).

Didapatkan angka pasien bergejala yang menjalani pengobatan sebanyak 514.434 individu. Maka besaran parameter laju pasien bergejala menjalani pengobatan $(\tau)$ sebesar

$$
\tau=\frac{514434 / 11}{10562088}=0,004427 / \text { bulan }
$$

Dengan menginput nilai parameter yang telah ditemukan pada bilangan $\mathfrak{R}_{0}$, didapatkan

$$
\Re_{0}=0,851115
$$

Bilangan $\Re_{0}<1$ dapat diartikan individu yang terinfeksi menghasilkan kurang dari 1 infeksi baru dan penyakit perlahan akan musnah. Dikarenakan bilangan $\mathfrak{R}_{0}$ kurang dari 1 , maka model/sistem stabil di titik ekuilibrium bebas penyakit. 
Kemudian diinput nilai parameter ke dalam titik ekuilibrium bebas penyakit pada persamaan (4.25). Didapatkan nilai-nilai titik bebas penyakit $E_{1}\left(s, e, a, i, t_{1}, t_{2}, r\right)$ sebesar $E_{1}(1.748001,0,0,0,0,0,0)$.

Kemudian dilakukan simulasi pada setiap kompartemen yang ada pada model menggunakan program Maple. Untuk kompartemen rentan pada saat $t=0$ yaitu $S(0)=0$ dikarenakan belum ada individu yang lahir ke dalam populasi. Kemudian untuk kompartemen $E, A, I, T_{1}, T_{2}$, dan $R$ pada saat $t=0$ dipilih nilai awal 1 agar terlihat penurunan subpopulasi yang terinfeksi penyakit seiring penyakit menghilang dari populasi. Berikut disajikan grafik-grafik plot perubahan jumlah masingmasing kompartemen terhadap waktu $t$.

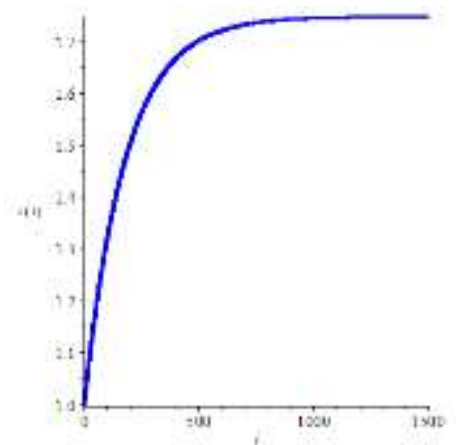

GAMBAR 2. Plot Perubahan Jumlah Individu Kompartemen $S$ terhadap waktu $t$

Gambar 2 menunjukkan perubahan jumlah individu dari waktu ke waktu. Titik ekuilibrium bebas penyakit $S$ bernilai 1.748001 dan dapat dilihat bahwa plot mulai stabil atau mendatar pada titik tersebut. Ini menandakan bahwa subpopulasi $S$ stabil ke titik bebas penyakit. Meningkat tajamnya plot subpopulasi $S$ dikarenakan masuknya individu baru lahir ke dalam populasi dan mulai stabil dalam 1500 bulan. Jumlah individu kompartemen $S$ pada waktu $t$ mulai mendatar dalam waktu 1500 bulan dikarenakan individu yang keluar ke kompartemen lain.

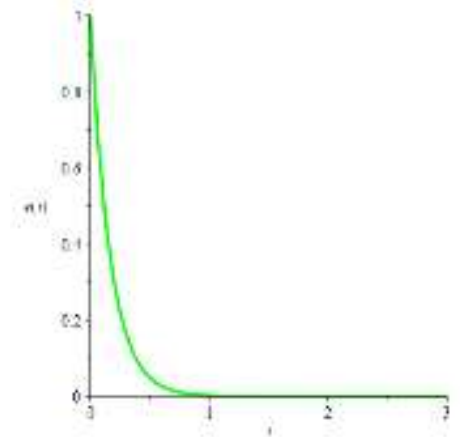

GAMBAR 3. Plot Perubahan Jumlah Individu Kompartemen $E$ terhadap waktu $t$

Dengan dipilih nilai awal 1 , yaitu $E(0)=1$, didapatkan plot menurun pada jumlah individu kompartemen $E$ pada waktu ke-t. Dapat dilihat plot mulai stabil kurang dari 1 bulan. Hal ini disebabkan kompartemen $E$ menampung individu-individu yang terpapar dan masa inkubasi yang dijalani hanya 5 hari atau $\frac{1}{6}$ bulan. 


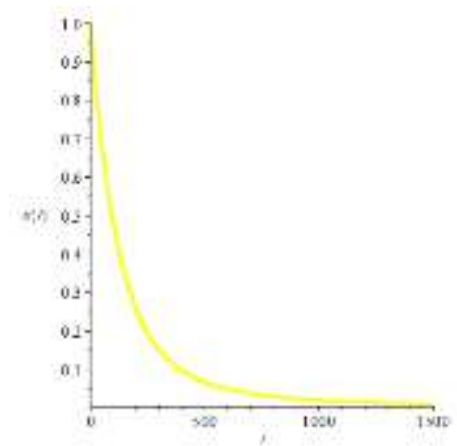

GAMBAR 4. Plot Perubahan Jumlah Individu Kompartemen $A$ terhadap waktu $t$

Dengan dipilih nilai awal 1, terlihat penurunan plot kompartemen $A$ terhadap waktu $t$. Dapat dilihat bahwa plot mulai stabil dalam waktu 1500 bulan. Menurunnya plot disebabkan oleh hampir keseluruhan individu kompartemen $A$ sudah ke kompartemen lain, ada yang sudah masuk kompartemen orang sembuh $(R)$ setelah menjalani isoman, ada yang meninggal alami, dan ada juga yang meninggal akibat Covid-19.

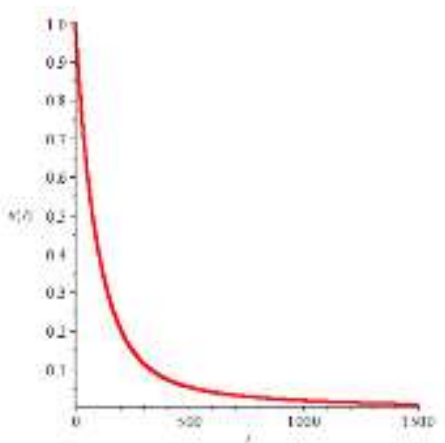

GAMBAR 5. Plot Perubahan Jumlah Individu Kompartemen $I$ terhadap waktu $t$

Dengan dipilih nilai awal 1, terlihat penurunan plot kompartemen $I$ terhadap waktu. Kompartemen $I$ mulai stabil dalam waktu 1500 bulan. Keadaan mulai stabil dikarenakan hampir seluruh individu sudah pindah ke kompartemen lain, ada yang sudah sembuh setelah menjalani isoman atau perawatan rumah sakit, ada yang meninggal alami, dan ada juga yang meninggal dari Covid-19 ini.

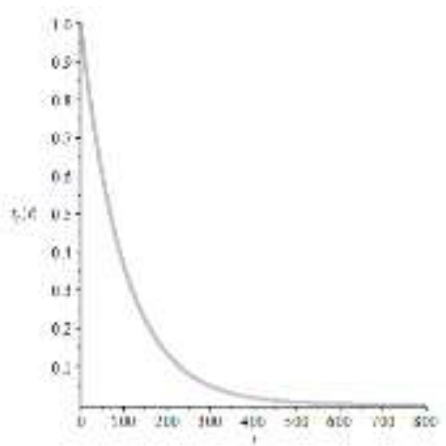

GAMBAR 6. Plot Perubahan Jumlah Individu Kompartemen $T_{1}$ terhadap waktu $t$

Dengan dipilih nilai awal 1, terlihat perubahan jumlah individu pada kompartemen subpopulasi yang menjalani isolasi mandiri. Plot mulai stabil dalam waktu 800 bulan. Plot kompartemen $T_{1}$ mulai stabil dikarenakan jumlah pasien dari kompartemen $A$ dan $I$ mulai menurun, ada yang sudah sembuh, atau meninggal ketika proses isoman ini. 


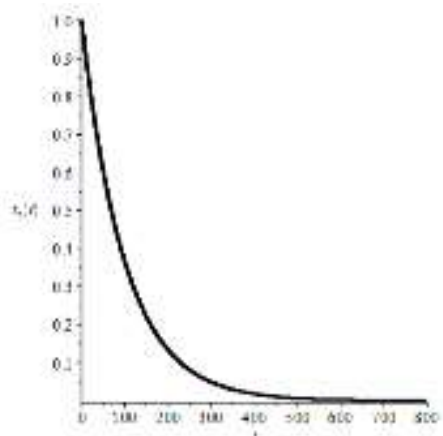

GAMBAR 7. Plot Perubahan Jumlah Individu Kompartemen $T_{2}$ terhadap waktu $t$

Dengan dipilih nilai awal 1 , yaitu $t_{2}(0)=1$, terlihat penurunan jumlah individu kompartemen $T_{2}$ terhadap waktu $t$. Dapat dilihat mulai stabil dalam waktu 800 bulan. Keadaan mulai stabil dikarenakan jumlah pasien dari kompartemen $I$ mulai menurun, ada yang sudah sembuh, atau meninggal ketika perawatan di rumah sakit.

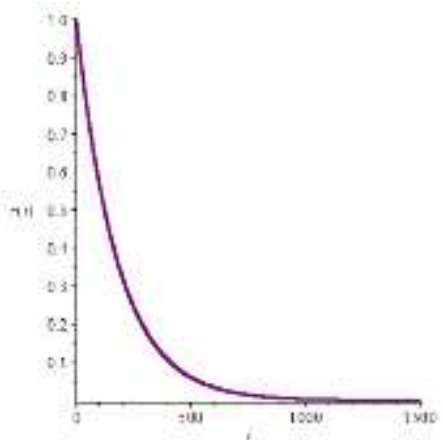

GAMBAR 8. Plot Perubahan Jumlah Individu Kompartemen $R$ terhadap waktu $t$

Diambil nilai awal 1 yaitu $r(0)=1$, didapatkan plot perubahan jumlah individu menurun. Dapat dilihat plot mulai stabil dalam waktu 1500 bulan. Jumlah individu yang sembuh setiap waktu $t$ semakin menurun disebabkan menurunnya pula jumlah individu yang menjalani pengobatan $T_{1}$ dan $T_{2}$.

\section{KESIMPULAN}

1. Model matematika penyebaran Covid-19 dibangun dengan memperhatikan data penyebaran Covid-19 di DKI Jakarta. Dapat dilihat bahwa pada penyebaran Covid-19 di DKI Jakarta terdapat dua subpopulasi yang dapat menyebarkan penyakit ( $A$ dan $I$ ), dan dua subpopulasi yang berisi individu yang menjalani pengobatan $\left(T_{1}\right.$ dan $\left.T_{2}\right)$.

Dengan demikian model terdiri dari 7 kompartemen, yaitu kompartemen individu rentan $(S)$, kompartemen individu terpapar dan menjalani masa inkubasi $(E)$, kompartemen individu infectious tanpa gejala $(A)$, kompartemen individu infectious bergejala $(I)$, kompartemen individu yang menjalani isolasi mandiri $\left(T_{1}\right)$, kompartemen individu yang menjalani perawatan rumah sakit $\left(T_{2}\right)$, dan kompartemen individu yang telah sembuh dari Covid-19 $(R)$. Model terdiri dari sistem persamaan diferensial dari tujuh kompartemen sebagai berikut:

$$
\begin{gathered}
\frac{d S}{d t}=\Lambda N-(\beta S I+\beta S A)-\mu S \\
\frac{d E}{d t}=\beta S I+\beta S A-\eta \omega E-(1-\eta) \omega E-\mu E \\
\frac{d A}{d t}=\eta \omega E-\zeta A-\mu A
\end{gathered}
$$


Analisis Penyebaran Penyakit Covid-19 dengan Pengaruh Pengobatan Isolasi Mandiri dan Pengobatan...

$$
\begin{gathered}
\frac{d I}{d t}=(1-\eta) \omega E-\rho \tau I-(1-\rho) \tau I-\mu I \\
\frac{d T_{1}}{d t}=\zeta A+(1-\rho) \tau I-\chi T_{1}-\mu T_{1}-\psi T_{1} \\
\frac{d T_{2}}{d t}=\rho \tau I-\chi T_{2}-\mu T_{2}-\psi T_{2} \\
\frac{d R}{d t}=\psi T_{1}+\psi T_{2}-\mu R
\end{gathered}
$$

2. Dengan menganalisa sistem dalam model non-dimensional, didapatkan titik ekuilibrium bebas penyakit dan titik ekuilibrium endemik.

Titik ekuilibrium bebas penyakit didapatkan ketika populasi keseluruhan terbebas dari penyakit. Oleh karena itu $a=0=i$. Didapatkan titik ekuilibrium bebas penyakit sebagai berikut:

$$
E_{1}\left(s, e, a, i, t_{1}, t_{2}, r\right)=\left(\frac{\Lambda}{\mu}, 0,0,0,0,0,0\right)
$$

Dapat dilihat dalam keadaan bebas penyakit, hanya kompartemen $S$ yang memiliki titik ekuilibrium yang bernilai $>0$.

Titik ekuilibrium endemik adalah titik ekuilibrium sistem ketika populasi tidak bebas dari penyakit. Dengan demikian nilai $a>0$ dan $i>0$. Hasil perhitungan titik ekuilibrium endemik $E_{2}\left(s^{*}, e^{*}, a^{*}, i^{*}, t_{1}^{*}, t_{2}^{*}, r^{*}\right)$ dari sistem sebagai berikut:

$$
\begin{aligned}
& s^{*}=\frac{(\mu+\omega)(\mu+\tau)(\mu+\zeta)}{\beta(\omega-\eta \omega)+(\mu+\zeta)+\beta \eta \omega(\mu+\tau)}, \quad e^{*}=\frac{\beta s^{*} i^{*}+\beta s^{*} a^{*}}{\mu+\omega}, \quad a^{*}=\frac{(-1+\eta) \omega\left(\Lambda-\mu s^{*}\right)}{(\mu+\tau)(\mu+\omega)}+\frac{\Lambda-\mu s^{*}}{\beta s^{*}}, \\
& i^{*}=\frac{\Lambda-\mu s^{*}}{\beta s^{*}}-\frac{\left(\Lambda-\mu s^{*}\right) \eta \omega}{(\mu+\zeta)(\omega+\mu)}, t_{1}^{*}=\frac{\zeta a^{*}+(1-\rho) \tau i^{*}}{\chi+\psi+\mu}, t_{2}^{*}=\frac{\rho \tau i^{*}}{\chi+\psi+\mu}, \text { dan } r^{*}=\frac{\psi t_{1}^{*}+\psi t_{2}^{*}}{\mu} .
\end{aligned}
$$

Dapat dilihat dalam keadaan penyakit menyebar, seluruh kompartemen memiliki titik ekuilibrium yang bernilai $>0$.

Analisis kestabilan dilakukan dengan membentuk matriks generasi selanjutnya dari sistem. Kemudian didapatkan bilangan $\Re_{0}$ sebagai berikut:

$$
\Re_{0}=\frac{\beta \Lambda \eta \omega}{\mu((1-\eta) \omega+\eta \omega+\mu)(\mu+\zeta)}+\frac{\beta \Lambda(1-\eta) \omega}{\mu((1-\eta) \omega+\eta \omega+\mu)((1-\rho) \tau+\rho \tau+\mu)}
$$

Setelah memasukkan nilai parameter-parameter sesuai data yang tersedia, didapatkan besaran bilangan $\Re_{0}$ sebesar 0,851115 .

Bilangan $\Re_{0}=0,851115$, berarti $\Re_{0}<1$. Bilangan $\mathfrak{R}_{0}<1$ menandakan sistem tidak stabil di titik endemik, melainkan sistem stabil di titik ekuilibrium bebas penyakit.

3. Plot masing-masing kompartemen menggambarkan bahwa penyakit Covid-19 akan menyerang populasi dan akan menghilang. Berdasarkan hasil simulasi, subpopulasi/kompartemen $S$ akan stabil dalam waktu 1500 bulan, kompartemen $E$ akan stabil dalam waktu 1 bulan, kompartemen $A$ akan mulai stabil dalam waktu 1500 bulan, kompartemen $I$ akan mulai stabil dalam waktu 1500 bulan, kompartemen $T_{1}$ akan mulai stabil dalam waktu 800 bulan, kompartemen $T_{2}$ akan mulai stabil dalam waktu 800 bulan, kompartemen $R$ akan mulai stabil dalam waktu 1500 bulan. Oleh karena itu, diperlukan persiapan fasilitas pengobatan sampai dengan penyakit menghilang dari populasi. 


\section{REFERENSI}

Banerjee, S. 2014. Mathematical Modelling: Models, Analysis, and Applications. CRC Press. Boca Raton, FL.

BPS Jakarta. 2021. Jumlah Penduduk Provinsi DKI Jakarta Menurut Kelompok Umur dan Jenis Kelamin 2018-2020. URL: https://jakarta.bps.go.id/indicator/12/111/1/jumlah-penduduk-provinsidki-jakarta-menurut-kelompok-umur-dan-jenis-kelamin.html. Diakses pada 7 September 2021.

Corona Jakarta. 2021. Daily Update Data Agregat Covid-19 Jakarta. URL: https://corona.jakarta.go.id/id. Diakses pada 6 September 2021.

Diskominfotik DKI Jakarta. 2021. Pelaporan Kelahiran di DKI Jakarta Tahun 2020. URL: https://statistik.jakarta.go.id/infografis/pelaporan-kelahiran-di-dki-jakarta-tahun-2020/. Diakses pada 7 September 2021.

Diskominfotik DKI Jakarta. 2021. Pelaporan Data Kematian Penduduk DKI Jakarta Sepanjang Tahun 2020. URL: https://statistik.jakarta.go.id/infografis/pelaporan-data-kematian-pendudukdki-jakarta-sepanjang-tahun-2020/. Diakses pada 7 September 2021.

Driessche, P., Watmough, J. 2002. Reproduction Numbers and Sub-threshold Endemic Equilibria for Compartmental Models of Disease Transmission. Mathematical Biosciences 180 (2002) 29-48. Elsevier. https://www.sciencedirect.com/science/article/pii/S0025556402001086 [28 Okt 2020]

Krishna, M. V., Prakash, J. 2020. Mathematical Modelling on Phase Based Transmissibility of Coronavirus. Mathematical Biosciences. Volume 180. Issues 1-2. Hal 29-48. lhttps://doi.org/10.1016/j.idm.2020.06.005 [21 Okt 2020]

Otunuga, O. M., Mobolaji, O. O. 2019. Qualitative Analysis of a Stochastic SEITR Epidemic Model with Multiple Stages of Infection and Treatment. https://doi.org/10.1016/j.idm.2019.12.003 [21 Okt 2020]

WHO. 2020. Transmission of SARS-CoV-2: implications for infection prevention precautions. Scientific Brief. 